\title{
2017 Recipients of the Fund for Latino Scholarship
}

\section{A} PSA introduces the 2017 recipients of grants from The Fund for Latino Scholarship. The Fund's primary goal is to encourage and support the recruitment, retention, and promotion of Latina/o political scientists (especially students and tenure-track junior faculty). The secondary goal is to support research on Latino politics in the United States (especially students and tenure-track junior faculty). Grants are made to individuals, institutions, and projects whose purposes most clearly match the goals of the Fund, and whose proposals most persuasively demonstrate capacity for successful completion. The Fund for Latino Scholarship is an APSA Centennial Center Research Grant.

\section{RUDY ALAMILLO}

Rudy Alamillo is a PhD candidate in the department of political science at the University of California, Riverside. Alamillo's research interests include Latino voting

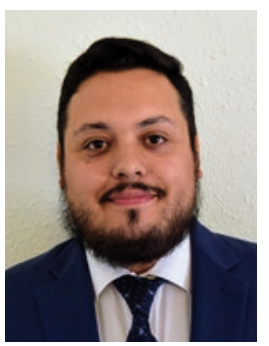

behavior, campaign appeals, and crossracial mobilization. His dissertation looks at how nonco-ethnic candidates can benefit from shared ethnicity by using a package of campaign appeals called identity-based appeals. Alamillo's dissertation contends that for certain voters, identity-based appeals can trump party and policy cues when it comes to vote choice. His dissertation uses a mixed-methods approach and includes interviews and analysis of archival records as well as ecological inference and conjoint experiments. Alamillo's most recent article, "Chameleon Politics: Social Identity and Racial CrossOver Appeals," can be found in Politics, Groups, and Identities. With support from the Fund for Latino Scholarship, he will travel to the 2017 Annual Meeting of the American Political Science Association where he will attend panels in his areas of interest as well as various business meetings and receptions. He hopes to advance the goals of the fund by obtaining a tenure track position and continuing his mentorship of students from underrepresented backgrounds.

\section{TERESA YOLOTL GOMEZ}

Teresa Yolotl Gomez has recently graduated from San Jose State University with a BA in political science and a minor in Spanish. She is planning to apply to $\mathrm{PhD}$ programs in

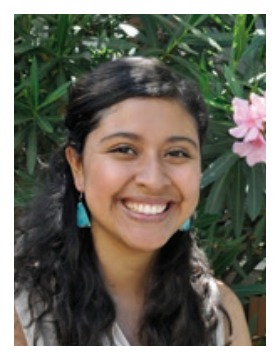
political science this fall. She is interested in using mixed methods to understand the relationship between women, citizenship, and social movements. Gomez studied abroad in Spain for an entire academic year. In her year abroad along with her work experience, Gomez has found that migrant women practice citizenship drastically different than men. As an undergrad she interned for Santa Clara County, Asian Law Alliance, and Congresswoman Zoe Lofgren. She worked at the Cesar Chavez Community Action Center where she cofounded the Sembradores literacy program that works with low-income elementary students. Gomez was awarded by her university for her leadership on campus and was the keynote speaker for the 2017 Strong Girls Strong Women Conference, hosted by the Office of Women's Policy of Santa Clara County. With the generosity of the APSA Fund for Latino Scholarship, Gomez will attend the APSA 2017 Annual Meeting. Attending the Annual Meeting will help her in her process of applying to graduate school by exposing her to potential programs that align with her research interests.

\section{ALFREDO GONZALEZ}

Alfredo Gonzalez is a doctoral candidate in the department of political science at the University of Chicago. His research is located at the intersection of race and politics, American political development, naturalization policy, and military sociology. In his dissertation, "Other Than Honorable: The Decline of Citizenship-forService," Gonzalez offers an explanation to the growing limitations and restrictions non-citizen service members are faced with when attempting to normalize their citizenship status during and after their active service. This archival study focuses on a critical conjuncture between WWII (last period guaranteeing citizenship-for-service) and the 1965 HartCeller Act (established residency and service requirements for naturalization) to demonstrate how Congress legislatively gained power to restrict, and at times deny, non-white immigrant service members access to naturalization-regardless of military service. With support from the Fund for Latino Scholarship, Gonzalez will gather primary data from the Patrick McCarran archives, author of the 1952 Immigration and Nationality Act, located at the Nevada Historical Society. Gonzalez is a veteran of the United States Marine Corps and served in Iraq during the initial American invasion as an infantry rifleman.

\section{MARICRUZ OSORIO}

Maricruz Osorio (MFP 2017-2018) graduated from Knox College, where she was a McNair Fellow and completed two research projects on the topics of race,

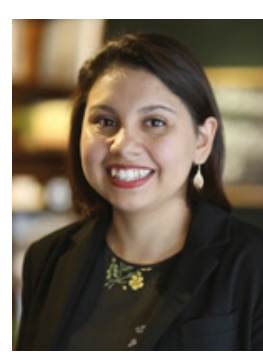
social justice, and intergroup dialogue. She is currently a graduate student at the University of California, Riverside where she is a Eugene Cota-Robles Fellow. Her current research agenda focuses on race, immigration, refugees, gender, and intersectional theory. Osorio has recently presented her ongoing work at the Midwest Political Science Annual Meeting and at the Politics of Race, Immigration, and Ethnicity Consortium. The grant from the Latino Fund will allow for crucial travel and other related expenses to interview refugee women and officials. These funds allow for the progression of the ongoing project on the political socialization of refugees.

\section{ESTEFANIA CASTAÑEDA PÉREZ}

Estefania Castañeda Pérez (MFP 20162017) is a second year PhD student at University of California, Los Angeles (UCLA) studying international relations and race, 


\section{ethnicity, and poli-} tics. Her research and educational experiences have been transformed by her trans-border lifestyle between Tijuana, Mexico and San Diego, California. Her current project, which is inspired by her own experiences at the border, explores the impact of border controls at the US-Mexico ports of entry on cross-border commuters' political integration in the United States. This project is an extension of a senior honors thesis she completed as an undergraduate student at San Diego State University. In her thesis, she explored the different experiences and perceptions of border policing from cross-border commuters in the pedestrian lanes at the Tijuana-San Ysidro border. Her project will make contributions to Latino scholarship by providing original data on cross-border commuters, a population that has remained understudied in the border and migration studies literature. The interactions between commuters and Customs and Border Protection (CBP) officers provide insight into how the state defines who can "legitimately" cross, even when the majority are authorized border crossers, and whether negative border experiences result in feeling more exclusion in the United States, particularly during a political climate that pushes for increased securitization at the border. Her research contributes to the Fund's goals by examining whether notions of trust, exclusion, and citizenship at the border transform Latino political behavior. Furthermore, this project will serve as a stepping-stone for future work on similar populations in transit, which include refugees and other types of migrants. Prior to UCLA, Pérez was a Fulbright English Teaching Assistant in Madrid and worked to prepare high school students to compete in Model United Nations competitions. Currently, she is a Eugene V. Cota-Robles fellow at UCLA, and received the APSA Minority Fellowship Program award in 2016.

\section{HEATHER SILBER MOHAMED}

Heather Silber Mohamed is an assistant professor of political science at Clark University. Her research interests include Latino politics, immigrant socialization and

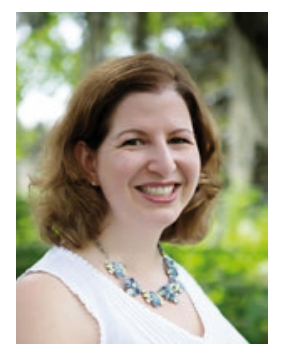

participation, immigration policy, and identity politics in the United States, with a focus on the influence of race, class, and gender. Her book, The New Americans? Immigration, Protest, and the Politics of Latino Identity (University Press of Kansas 2017) analyzes how protest and the immigration debate influence Latinos' sense of belonging in the United States. The book focuses primarily on the unprecedented wave of Latino-led protests that occurred in 2006, in which millions of people mobilized across the country in opposition to a farreaching immigration proposal pending before the US Congress. Silber Mohamed also worked for six years on Capitol Hill, in both the Senate and the House of Representatives. She will use her award from the Fund for Latino Scholarship to support an ongoing collaboration with Emily Farris (Texas Christian University) to develop and code a database of images accompanying news stories about immigration from major national news magazines over a 10-year period. Their analysis of this data explores the intersections of gender and race/ethnicity, as well as portrayals of borders and criminality, in the media's coverage of the immigration debate.

\section{JULIANA RESTREPO SANIN}

Juliana Restrepo Sanin is a $\mathrm{PhD}$ candidate in political science at Rutgers University. Her research interests include women's representation, comparative politics, and Latin American politics. She is currently writing her dissertation, "Violence against Women in Politics in Latin America." There, she analyzes the regional debates surrounding the concept of

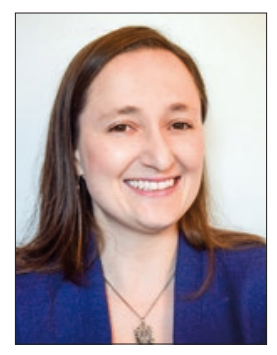
violence and harassment against women in politics and the legislative measures designed to combat this phenomenon. She is currently working on a project on citizens' perceptions and engagement with the justice system in Colombia, Chile, and the United States. She has also worked as a consultant for the Netherlands Institute for Multi-Party Democracy in Colombia and the Inter-American Commission on Women. Thanks to the support from the Latino Scholarship Fund, Restrepo Sanin will attend the 2017 APSA Annual Meeting where she will present a paper on violence against women in Colombia.

\section{UNIVERSITY OF MARYLAND} CENTER FOR AMERICAN POLITICS AND CITIZENSHIP (INSTITUTIONAL AWARD)

The Fund is proud to award the University of Maryland Center for American Politics and Citizenship, directed by Stella M. Rouse, associate professor in the

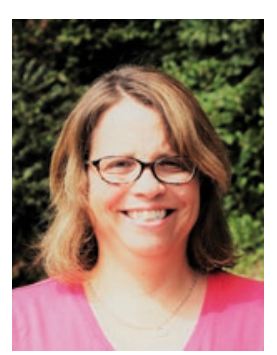
department of government and politics and associate director of the University of Maryland Critical Issues Poll. Rouse's research and teaching interests focus on Latino politics, minority politics, millennial politics, state politics, and immigration. She is the author of the book, Latinos in the Legislative Process: Interests and Influence (Cambridge University Press, 2013)-voted as one of the best political science books of 2013 by The Huffington Post. She is currently working on her second book, titled The Politics of Millennials: Political Beliefs and Policy Preferences of America's Most Diverse Generation. Rouse has published articles on group dynamics and cosponsorship, religion and ethno-racial political attitudes, Latino representation and education, and millennials and immigration. Her research has been funded by the Ford Foundation and the National Science Foundation. Rouse is a native of Colombia. She fluently speaks, reads, and writes Spanish. The APSA Fund for Latino Scholarship will assist in the recruitment of a Latino undergraduate student to work as a fellow in the Center for American Politics and Citizenship, which Rouse directs. The student will have the opportunity to work hand-in-hand with faculty and graduate students to collect data, conduct research, and write scholarly research. These skills will be invaluable in preparation for pursuing a graduate education. 